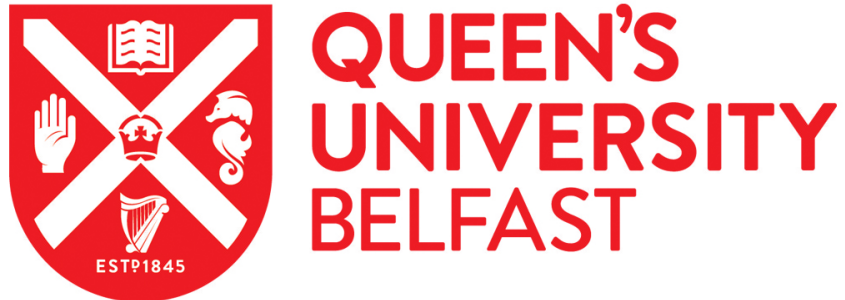

\section{Social workers: a new precariat? Precarity conditions of mental health social workers working in the non-profit sector in Greece}

Pentaraki, M., \& Dionisopoulou, K. (2019). Social workers: a new precariat? Precarity conditions of mental health social workers working in the non-profit sector in Greece. European Journal of Social Work, 22(2), 301-313. https://doi.org/10.1080/13691457.2018.1529664

\section{Published in:}

European Journal of Social Work

\section{Document Version:}

Peer reviewed version

Queen's University Belfast - Research Portal:

Link to publication record in Queen's University Belfast Research Portal

\section{Publisher rights}

(c) 2018 Informa UK Limited, trading as Taylor \& Francis Group. This work is made available online in accordance with the publisher's policies. Please refer to any applicable terms of use of the publisher.

\section{General rights}

Copyright for the publications made accessible via the Queen's University Belfast Research Portal is retained by the author(s) and / or other copyright owners and it is a condition of accessing these publications that users recognise and abide by the legal requirements associated with these rights.

Take down policy

The Research Portal is Queen's institutional repository that provides access to Queen's research output. Every effort has been made to ensure that content in the Research Portal does not infringe any person's rights, or applicable UK laws. If you discover content in the Research Portal that you believe breaches copyright or violates any law, please contact openaccess@qub.ac.uk. 


\author{
Social workers: a new precariat? Precarity conditions of mental \\ health social workers working in the non-profit sector in Greece

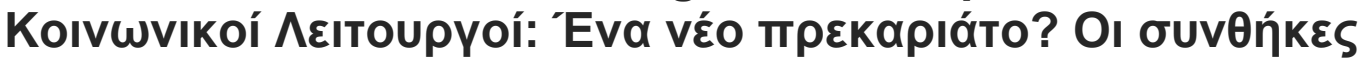 \\ $\varepsilon \pi$

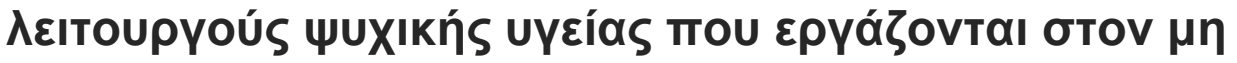

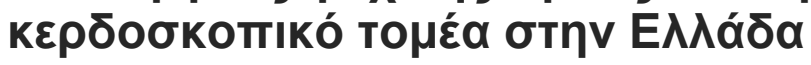 \\ Maria Pentaraki \& Konstantina Dionysopoulou \\ Published online: 13 Oct 2018 \\ Download citation \\ https://doi.org/10.1080/13691457.2018.1529664
}

\author{
Pentaraki, M., \& Dionysopoulou, K. (2018). Social workers: a new precariat? Precarity \\ conditions of mental health social workers working in the non-profit sector in \\ Greece. European Journal of Social Work, 1-13.
}

\title{
Introduction
}

Traditionally, in western countries, social workers have dealt directly or indirectly with the phenomenon of precarity through the lives of service users who lived in poverty (Parrott, 2014; Saar-Heiman, Lavie- Ajayi, \& Krumer-Nevo, 2017; Shamai, 2017; Sheedy, 2013). They have also experienced dimensions of precarity through the poverty they experience as social work students (Gair \& Baglow, 2017, and though insecurity and anxiety created through the neoliberal management conditions experienced in their professional lives (Duschinsky, Lampitt, \& Bell, 2016; Seifert, Messing, Riel, \& Chatigny, 2007; Smith et al., 2016).

However, during the last decade, in many western countries, including Greece, precarity as inse- curity is being experienced by social workers not only in their professional lives but also in their per- sonal lives (Pentaraki, 2017a). This had led to the phenomenon of shared austerity reality in which common insecure conditions are experienced both by service users and public sector social workers, albeit to different degrees (Pentaraki, 2017a). However, even though public sector social workers' lives have been adversely affected materially, the major issues identified centred around an existential insecurity related to the insecure social reproduction conditions that their children and their parents faced and their inability to help them out effectively. These experiences were con- structed by the implementation of neoliberal austerity policies imposed to Greece by the TROICA, (a transnational decision making body comprised by the European Union, the European Central Bank and the International Monetary Fund) which reflected wider socio-economic global transformations (for a more detailed analysis see Pentaraki, 2013, 2015, 2017a, 2017b).

This paper moves the discussion forwards by focussing on precarity as experienced by social workers working in the non-profit sector in their own lives. By doing this it aims to explore increasing precarity amongst social workers; furthermore, it examines its consequences in their lives and then develops a conceptual framework to 
understand the origins, entrenchment and effects of precarity amongst social workers. It draws on findings from a small pilot study of mental health social workers working in the non-profit sector in Greece documenting their precarious experiences. However, this is part of a larger explorative study exploring the perceived impact of austerity measures and economic crisis on social workers in Greece. The decision to report on this subset of the sample was based on the consistent theme of being unpaid during the time of the interviews.

Before the research is presented, the paper will first briefly outline the socio-economic context of rising inequalities and then define issues of precarity.

\section{Socio-economic context}

During the last four decades the welfare state in western countries has faced reconfigurations along neoliberal lines such as social spending cuts and the transferring of welfare services from the state to the private sector (Harvey, 2005; Lorenz, 2017). These welfare reconfigurations have been extended since the 2008 global financial crisis, under the pretext of a crisis of public finances (Levitas, 2012; Pen- taraki, 2013). Despite evidence that the crisis was primarily caused by financial capital's greedy and predatory practices of its banking sector, the welfare state was targeted. This was reflected by the trans- fer of public money from the poor to the rich in order to fund "the rescue of the world banking system, the bailout of corporations, and the salvage of the investment portfolios of the wealthy" (McNally, 2011, p. 5). These changes affected those employed in public services or in outsourced services as well as the quality of the provided services (Cunningham, Baines, \& Shields, 2017; Pentaraki, 2017a, 2017b).

One of the countries that has been most seriously affected by neoliberal reconfigurations is Greece (Pentaraki, 2013, 2015, 2017a, 2017b). Despite evidence that the crisis in Greece and in other countries, e.g. Portugal, Spain, Italy and Ireland, was not caused by social spending, social spending cuts since the onset of the crisis have amounted to almost 60\% in Greece (Karamessini, 2015). However, the effects have been magnified in Greece as elsewhere in southern Europe due to the familialist welfare state model (Papadopoulos \& Roumpakis, 2013). Although, these issues are often presented by the mainstream media as being exceptional to Greece in order to make an argu- ment that Greece brought this upon itself (Pentaraki, 2018a), there is no evidence to support this (Pentaraki, 2013). Fundamentally, the issues that Greece faces reflect wider socio-economic trans- formations experienced world-wide (Pentaraki, 2013, 2015, 2017a, 2017b, 2018a, 2018b; Pentaraki \& Speake, 2015). For example, the context of rising global inequalities is reflected in the concentration of wealth in the hands of few. According to the international Anti-poverty Development Organization Oxfam Report (Oxfam, 2017) the eight wealthiest people in the world own as much wealth as half the world. Also, the Gini coefficient, which is an inequality measure used in economics, and intended to represent the income or wealth distribution of a nation's residents, reflects the almost universal rising level of inequalities world-wide (OECD, 2016). These increasing levels of inequality have led to rising levels of precarity, long characteristic of life in the non-west (Comaroff \& 
Comaroff, 2012) that now have moved to the west and are not only experienced by marginalised population such as immi- grants, unskilled workers and young people but also are now being felt by middle class university- educated professionals. In order to explore this further, the next section will outline the major scho- larly work on precarity.

\section{Defining precarity and precariat}

Standing (2011) has popularised the term precariat in the academic literature. He presents precariat as a distinctive socio-economic group and "a class in the making" (Standing, 2011, p. 7). The compo- sition of the precariat comprises an ever-growing number of people across the world who live and work precariously. They are usually employed in short-term jobs, without recourse to stable occu- pational identities, careers, stable social protection or relevant protective regulations. These insecure workers have no collective bargaining power and are being abandoned by the traditional working class organisations, most notably the trade unions.

The retrenchment of security (related to labour market, employment, job, work, skill production, income and representation) is a main dynamic of the process of precarisation. Migrants make up a large share of the world's precariat. Standing (2011) alludes to the precariat as being a distinct and separate group, contrasted to "the salariat', a group that is often employed by the state in public administration and the civil service and is defined by secure employment, sick pay and paid holidays. However, this contrasted group does not seem to exist as much as Standing claims since social spending cuts have undermined public sector employment. In Europe, this consequence has effectively challenged the existence of the so called European Social Model (Hermann, 2014b).

Most of the scholarly literature, including Standing's work, uses the term precarious to describe atypical work such as short-term contract and casual work but, as Tompa, Scott-Marshall, Dolinschi, Trevithick, \& Bhattacharyya (2007, p. 210) argue, "an exclusive focus on the nature of the labour con- tract obscures the fact that many labour-market experiences in the new economy of neoliberal capit- alism - including those that fall under the banner of standard work - exhibit characteristics that could be experienced as insecure, and thus, potentially detrimental to health and well-being".

This paper moves beyond Standing's understanding of the precariat in a similar tradition to Vosko, MacDonald and Campbell (2009) and Tompa et al. (2007) amongst other scholars. It uses the term to discuss dimensions of insecurity that exist in all jobs such as social work jobs that have an occupational identity not just in atypical jobs (Tompa et al., 2007; Vosko, McDonald, \& Campbell, 2009). It also extends the term precarity beyond the realm of work to discuss the consequences of insecure employment relations on workers' personal lives (Neilson \& Rossiter, 2005).

Thus, in this paper 'precarious' is used to describe economic and social vulnerability and unstable, insecure, less protected work (Tompa et al., 2007). In line with this conceptualisation, precarity might be experienced differently and to varying degrees 
by different groups of people and to national con- texts and welfare regimes.

However, underlining these experiences is a generalised sense of insecur- ity due to material and psychological vulnerability resulting from neoliberal reforms. This can be observed even in countries such as Sweden. For example, Näsström and Kalm (2015) discuss that con- ditions of precarity have emerged in Sweden and in response to these 'The Precariat', an activist network, has been formed (Näsström \& Kalm, 2015). Also, Andersen, Schoyen and Hviden discuss that even in Scandinavian countries neoliberal reforms have been implemented which have brought some rising levels of inequalities, insecurity and damage to the welfare state (Andersen, Schoyen, \& Hviden, 2017).

The paper maintains that precarious conditions are embedded in the current structures of neolib- eral capitalism (Casas-Cortés 2014; Kalleberg, 2009, 2011, 2013; Lee \& Kofman, 2012; Mahmud, 2015; Millar, 2017).

\section{Research study}

This is a small qualitative pilot study which is part of a larger study exploring the perceived impact of austerity measures and economic crisis on social workers in Greece. The study reported here consists of nine face to face, in depth, semi structured interviews conducted between September and Decem- ber 2012 with mental health social workers in the non-profit mental health sector. This homogeneity resulted in data saturation, as reflected in the consistent theme that emerged - that participants had not been paid for four months, on average, during the time of interviews thereby leading to experi- ences of precarity. The paper reports on their precarity.

The average length of each interview was 55 minutes. Each participant gave consent, having been informed about the research and potential publication of the content of the interviews and assured on matters of confidentiality and anonymity. Accordingly, their geographical locations were described in very general terms. Ethical research procedures were followed by the relevant university ethics committee.

The authors conducted the interviews in Greece, which were recorded, transcribed and then the- matically organised by them to identify, categorise and analyse themes and patterns within the data (Braun \& Clarke, 2006).

The non-profit mental health sector

All the participants worked in the non-profit mental health sector which emerged out of the psychia- tric reform programme within a context of a neoliberal European agenda. More specifically they worked in mental health mobile units, residential care and day centres for mental health users with severe psychiatric disorders. A brief introduction of the reform programme provides context for the resultant precarity identified. The psychiatric reform programme was initiated in Greece in 1984 through the Commission of European Communities (EEC Regulation No 815/84) to address the inadequate functional capacity of the mental health system to meet mental health needs of the Greek population and provide effective community based services. 
However, this reform, implemented through the programme Psychargos, not only sought to address the needs of the mental health system through the advancement of de-institutionalisation and community mental health services but also to impose neoliberal funding models based on a competitive market agenda. This resulted in part of mental health service provisioning being outsourced/contracted out to private or non-profit organisations, which is a key feature of neoliberalism (Froud, Johal,

Moran, \& Williams, 2017). This "new" sector was characterised by non-consistent funding. Similarly, instability in finances due to neoliberal restructuring has been identified in other western countries, such as Canada (Cunningham et al., 2017).

The mental health sector in Greece was one of the first state welfare provision services to be pri- vatised/contracted out. Clearly, the outsourcing of state services (Evans, Richmond, \& Shields, 2005) can be found across western countries and has expanded to cover a variety of public services such as social services, health, home care, and education (Harvey, 2005). It has been argued that the Psychar- gos reform programme has resulted in incomplete reform, as evidenced in the underdevelopment of sectorisation, adequate primary care policies, inter-sectoral coordination and specialised services - a difficult situation which is further undermined by the adverse impact of the current financial crisis (Giannakopoulo \& Anagnostopoulos, 2016).

\section{Participants}

Participants were selected using convenience sampling. All participants were at the time of the inter- views working at the non for profit mental health sector. The participants' ages ranged from 27 years to 32 years with an average age of 30 years. There were seven women and two men, all white and born in Greece. All participants were holders of an undergraduate social work degree, two had also a masters' level degree and five of the participants were on psychotherapeutic training programmes. The majority of them worked in the greater area of Athens. The social workers interviewed who did not work in Athens but worked in other cities also had urban, semi-rural and rural, and other remote settings in their area of professional practice. Their experience as mental health social workers ranged from three to six years. The average years of social work experience was 5.5 years. Their length of employment at the present employer ranged from one year to six years.

Their narrations of their experiences are utilised to provide testimony of the nature and impacts of precarity in their professional and personal lives. In order to provide anonymity for the participants they are provided with fictive names.

\section{Findings}

The findings present a picture of social workers living and working in increasing insecure and/or pre- carious conditions. The consequences of these experiences can cause emotional distress, anxiety and burn-out. Despite this insecurity/precarity, all the participants expressed a concern about the lives of the service users and the future 
of mental health services. Insecurity has been experienced as an all- encompassing phenomenon influencing all aspects of the social workers' lives, both personally and professionally. The findings are presented by focussing on the insecurity experienced by the partici- pants 1) in their personal lives and 2) in their professional lives.

\section{Insecurity in participants' personal lives}

The main theme that emerged is the impact on the social workers' of not being paid for many months. At the time of the interviews, none of the participants had been paid for a long time, on average for a period of four months. This non-payment/delay in payment has caused insecure con- ditions that have adversely affected the participants' material conditions and general well-being.

Deterioration of payment patterns and its consequences

It was reported by Eleni that despite the fact that difficulties in the consistency of payments existed previously, this is now the most difficult time. "We are four and half months unpaid [...] this was not happening before to this extent [...]. This is the most difficult time compared to previous times." The previous difficulties to which she alludes seem to be related to the outsourcing competitive based funding model, which did not have a continuous funding stream. This delay in payment has changed the participants' living conditions adversely. They cannot afford the basic necessities of life, including housing insecurity and fuel poverty. Sofia, on this issue states:

[...] I stay at my parents' home. This house is incomplete, it has no floors, it is not heated, [...] if I did not have this house I do not know if I could continue working given the way of payment and all of this situation [...] whenever we get paid a debt is redeemed, then there is not much money left for anything else, $[\ldots]$,

She continued to articulate the seriousness of the situation:

1.

[I]justsurvive,everydayisjustwork, home,home,work, whichbringsexhaustion,mentalexh aus- tion [...]. The truth is that I'm [...] worried about it, I think it's serious, I think it's not just me, I'm facing it, and other people are confronted by it, I wonder where will it take us?

The above quotation reflects experiences of precarity surrounding both current survival needs and prospects for the future. Sofia explains that this is not only applies to herself for but also for the whole community. She highlights the critical supporting role of her family. This theme of the supporting role of families and friends was repeated by the other participants. Anna acknowledges their important role by stating "I cannot cope well, of course, without the help of my neighbours and my relatives, etc. $[. .$.$] ". However, Eleni was concerned for how long families and friends could$ provide help in the future:

[...] things are more difficult than before as [my friend] cannot give me the money that she used to lend me. Just because the whole situation is more difficult than before because now she faces her own issues. 
Although the help of families and friends was seen as invaluable, there was some embarrassment and sadness that the conventional intergenerational solidarity dynamics have been switched. This sense of embarrassment may suggest negative psychological consequences of the crisis to the participants. Dina stated:

[I]t is really hard, what should I say, that parents [both sets] help? We [she and her husband] should be ashamed. They [the parents] contribute though [..] they live in a rural area [...] so they provide fruit, vegetables, meat. But this makes us sad since we should be helping them as they have already done their duty to raise us, but instead of this we still ask for their help.

Sofia could not take the stress anymore and was searching for alternative employment, but finding it difficult. Georgia also tried to make ends meet by having an additional job in the hospitality sector but the demands of working two jobs were very hard.

Concerns were not only about their future professional opportunities and development but also how these issues impacted these issues impact their personal lives and life course, including having children. These were clearly expressed by Dina when she said:

Of course, there is no plan to have a child, even though I really wanted it, it is so scary [...]

In addition to the important issues of every day to day survival, such as heating and food, there were also reports of their inability to afford a range of other things such as travel expenses (including bus ticket to get to work), clothing expenses, social outings and gym membership. Combined, all of these reflect the deterioration of living conditions and quality of life.

All of these present and future concerns had created senses of 'going backwards' and an inability to progress and/or advance. This is articulated by Anna:

Sometimes I have a feeling of regression. I have been working for so long now and instead of going forwards I am going backwards? This affects me emotionally too, way beyond [the day to day practical issues of survival].

Insecurity in their professional lives: experienced in their personal lives including those gener-

ated by not being paid for their work for months, are also intensified by other insecurities in their working lives as Petros expressed:

... I have experienced a great sense of abuse ... when you have people with mental health needs, it's too difficult ... This is too abusive and having to simultaneously manage all your own anxieties and all your own practical and operational needs, it is very, very abusive ... The difficulties are many when you have not been paid for five months. The time comes when you cannot put gas in your car or buy a bus ticket to go to work [Furthermore at work] ...

... there were too many times when we could not feed the patients, so simple, we could not pay the electricity in the residential home and there was a danger of not having electricity, we could not pay the pharmacy and the pharmacist was threatening to leave us without medicines, we were under the threat of 
eviction, and the police came with the eviction notice etc. [...]

Petros considers his life to be injured and thus grievable (Butler, 2009). The above quote clearly reflects the all-encompassing feeling of insecurity and precarity faced by participants as they try to deal with both their own material insecurity and the insecurities faced by service users. Dina expressed similar frustrations and concerns, particularly about the elimination of services provided to service users. Views that were reflected by all the participants. Trying to manage both sets of inse- curity puts them in a position of double jeopardy (Abramovitz \& Zelnick, 2010) and leads them to question the future of mental health provision at different levels. These conditions threaten not only the future of mental health services but also the mental health of the participants. This is clearly expressed in the following remarks by Petros:

From moment to moment anything can happen and at any particular time there might not be any mental health cover $[\ldots]$ this thing is too stressful. Every day needs a 'plan b' and a 'plan c' such as considering the possible re- institutionalisation of the service users [...], possible communication with their families, to come to collect them. Tomorrow it may be that the boarding school does not work [...]. This causes inconceivable anxiety, unbelievable anxiety, which has a catalytic effect on the quality of my life. Now I do not care about my income because my income was bad. ... the amount of burn-out is immense, immense, immense.

The participants also focussed on the precarity and the vulnerability of many service users and reported that they had a sense of both professional and personal responsibility to fill gaps left unfilled by family and health/social services. As the needs of service users have intensified in the economic crisis, so too have the pressures on social workers, professionally and personally, as they are stretched (sometimes to the limit) to meet these needs. For Sofia this has meant feeling obliged to work uncompensated beyond her contracted hours to meet her professional obligations to the service users. Several social workers expressed that they were overstretched and concerned that they were on the road to burn-out, yet felt that they had to continue. On the other hand, Anna described how she loved her work even though there was a voice telling her that "in this difficult times you cannot continue having the kindness to persevere (tin eugeneia)".

\section{Discussion and conclusion}

The findings present a picture of mental health social workers facing rising levels of insecurity in their personal and professional lives (Abramovitz \& Zelnick, 2010; Pentaraki, 2017a). They reflect the situ- ation of social workers being part of the growing phenomenon of the working poor (Pradella, 2015), experiencing multiple dimensions of insecurity: surviving on loans, experiencing housing insecurity, reproductive insecurity (Chan \& Tweedie, 2015), fuel poverty and the inability to pay for their com- muting expenses to and from work and so forth.

The participants discussed facing rising levels of insecurity/precarity due to the increased insecur- ity surrounding not only their own lives and professional employment but also the service users' lives (Abramovitz \& Zelnick, 2010; Triliva \& Georga, 2014), the lives of their family/friends, community (Kretsos, 2014; 
Papadopoulos \& Roumpakis, 2013), future de-institutionalisation and the prospects for the mental health sector overall (Giannakopoulos \& Anagnostopoulos, 2016). They have been managing primarily because of the support of their families and friends but now that almost every- one's conditions have deteriorated further their insecurity intensifies, the implications of which could be explored more in future research.

The findings reflect an increased sense of vulnerability as insecurity in everyday life (Butler, 2009; Casas-Cortés, 2014; Neilson \& Rossiter, 2005), which emerge from the erosion of resources, policies and capacities that enable social reproduction (Papadopoulos \& Roumpakis, 2013). This results in a generalised sense of social precarity, which emanates from the neoliberal undermining of collective security, solidarity and thus systems of social reproduction (Lee \& Kofman, 2012; Lorenz, 2017; Lorey, 2015). This insecurity is all encompassing and inhabits the "microspaces of everyday life" (Ettlinger, 2007, p. 319). This, combined with the current socioeconomic conditions, "leads to an interminable lack of certainty, the condition of being unable to predict one's fate or having some degree of stability on which to construct a life" (Neilson \& Rossiter, 2005, p. 3).

The intensification of this insecurity is a reflection of the current socio-economic conditions (Bauman, 2013; Lorey, 2015; Mahmud, 2015; Pradella, 2015) from where the generalisation of employ- ment insecurity emanates (Beck, 1992). The participants discuss how the conditions they experience leads them to an inability to plan one's life, which parallels the experiences of psychologists working in Community Mental Health Centres in Greece (Triliva \& Georga, 2014, p. 149) who also experience the social milieu creeping into the psychotherapeutic relationship. Now it is not only immigrants, low skilled workers, young people, unemployed and service users who live in insecurity/precarity (Chan \& Tweedie, 2015; Mahmud, 2015), it is also university-educated professionals such as social workers in Greece, teachers in England (Ferguson, 2017), adjunct academics in many countries in Europe and in the USA (Ivancheva, 2015; Pathe, 2014; Thorkelson, 2016) i.e. almost everyone on the planet (Lee \& Kofman, 2012). The widening of social groups experiencing precarity reflects the global downwards convergence in terms of insecure working conditions and living standards overall (Hermann, 2014a, 2014b; Puig-Barrachina et al., 2014; Tompa et al., 2007). It also demonstrates the downward pressure on wages and jobs before and after the recent economic crisis. Instead of conditions in the global south improving, conditions in the global north have deteriorated (Comaroff \& Comaroff, 2012). These conditions reflect what Neilson (2015, p. 195) calls the "absolute general law" of increased pre- carity within neoliberal capitalism. This is a feature of living in an age of insecurity (Elliott \& Atkinson, 1999) which has been further intensified since the onset of the financial crisis.

The participants' precarious experiences are connected with both deteriorating material con- ditions and adverse psychological effects. Participants discussed feelings of abuse, embarrassment and sadness. These are emotions of insecurity affecting not only welfare professionals working in Greece but also employees working in public service delivery in countries such as England, which can be thought 
of as "emotions of austerity" (Clayton, Donovan, \& Merchant, 2015, p. 24). Furthermore, the participants discussed fears for the future that prohibit them from making future plans such as having children. This reflects the observed wider trend of birth rates declining during econ- omic recessions (Sobotka, Skirbekk, \& Philipov, 2011). Other participants talked about how they experienced 'burn-out' in trying to ameliorate the increased level of insecurity that the service users experience due to the economic crisis. Such lack of security, stability and predictability in their day to day personal and/or working lives seem to relate to what Neilson (2015, pp. 184-185) called "Existential anxiety, and is understood as mental unease induced by the selfreflexive percep- tion of life's precarious character, is intensified by the reality of deepening social and material precar- ity." These feelings can be related to the impact of the economic crisis, which Stolorow (2009) conceptualised as collective trauma, and allude to social workers being both wounded healers and fellow suffers (Golightley, 2017), as they experience the insecurities related to a shared austerity reality between themselves and the service users (Pentaraki, 2017a).

The participants were concerned about their own mental health and that of their service users. This concern reflects the general deteriorating conditions in Greece (see United Nations Human Rights, Office of the High Commissioner, 2015; Karamessini, 2015; Kokaliari, 2016; Economou, et al., 2016), which have led to the recognition by the UN Independent Expert Advisor that there is a huma- nitarian and human rights crisis in Greece (United Nations Human Rights, Office of the High Commis- sioner, 2015). As Salomon (2015) and others have contended, the denial of social rights under austerity has been substantial.

However, to recapitulate and conclude, these experiences reflect wider trends that are embedded in the current phase of neoliberal capitalism (Harvey, 2005). These experiences are primarily local manifestations of the global conditions of neoliberal capitalism and as such they have relevance for other countries. Furthermore, as the author has argued elsewhere (Pentaraki, 2017b, p. 1) "this understanding needs to inform the actions of social workers. It is important for these [experiences] to be contextualised within the socio-economic conditions in which they arise" in order for neoliberal capitalism to become a locus of intervention (Pentaraki, 2013; Pentaraki, 2017 b, p. 1). Towards this end, internationally social work education needs to offer the critical resources necessary for social workers to understand the structural causes of precarity both in their own and service users' lives so they can become the locus of intervention. This can be achieved through the incorporation of an international political economy (IPE) perspective. The IPE perspective is key to understanding these dimensions of insecurity/precarity as reflecting wider trends, including the rising level of inequalities (Oxfam, 2017), degrading labour conditions (Puig-Barrachina et al., 2014; Tompa et al., 2007) and changing relationships between the state and welfare provision (such as social spending cuts and models of outsourcing). It also includes the roles of neoliberal transnational decision making bodies such as the TROICA (Pentaraki \& Speake, 2015) in raising levels of precarity and poverty (Lorenz, 2017) etc. 
However, the remit of this paper is not to analyse these trends in detail as they have been success- fully analysed elsewhere (see amongst others Oxfam, 2017; Harvey, 2005; Pradella, 2015; Lorenz, 2017; Pentaraki, 2013; van Chung \& van Oorschot, 2010). Its purpose is to introduce the discussion of the experiences and consequences of precarity in the lives of mental health social workers as an all-encompassing experience that affects both them and the service users, within the context of neoliberal capitalism. This aim is congruent with the critical tradition of the international tradition of social work, which seeks to unravel global oppressive structures and how they impact on the social work profession (Pentaraki, 2017b).

Thus, it expands the social work scholarly literature on poverty and insecurity (Parrott, 2014; Sheedy, 2013) by adding the discussion of these as they affect social workers themselves. The abuse and the insecurity felt by the participants moves beyond the suffering they experience due to the poverty of others (Smith et al., 2016) as it includes their own. In doing so, this paper creates intersecting links between the social work scholarly literature which examines the adverse impacts of neoliberal capitalism on social work (Aronson \& Sammon, 2000; Baines, Davis, \& Saini, 2009; Dom- inelli, 1999; Fabricant, Burghardt, \& Epstein, 1992; Karagkounis, 2017; Pentaraki, 2017a, 2017b; Wallace \& Pease, 2011) and the scholarly literature on precarity (Baines, Cunningham, Campey, \& Shields, 2014; Baines, Cunningham, \& Shields, 2017; Casas-Cortés, 2014; Cunningham et al., 2016; Mahmud, 2015). In particular, this research extends knowledge and understanding of precarious experiences previously related only to work in which marginalised populations, such as immigrants, youth or unskilled workers are engaged. But more importantly this paper introduces precarity in the social work scholarly literature as a feature of social workers' professional and personal lives. The study shows how the processes of precaritisation are expanding, as precarity is now also experienced by professionals such as social workers and service users.

The growing sense of insecurity/precarity due to the impact of the current economic crisis cannot be understood effectively without reference to the dominant neoliberal fiscal response to the last financial crisis. This response has included spending cuts on social services in which most social workers practice and of these the majority are women (Karamessini \& Rubery, 2014). Future research needs to take this into account and explore gendered experiences of precarity (Vosko \& Clark, 2009). Another interesting research area would be a comparative analysis of the experiences of social workers with professionals working in other sectors of the social services. Furthermore, a comparative perspective of precarity experiences in dissimilar countries (especially in welfare regimes and labour regulations) could provide a more nuanced approach in terms of the effects of neoliberal capitalism.

In general, the growing sense of insecurity/precarity due to the impact of the current economic crisis cannot be understood effectively without reference to the dominant IPE perspective of neoliberal capitalism that has governed the world during the last 40 years, in which it is argued that competitive markets are the most effective way of promoting well-being (Harvey, 2005). This claim is refuted not only by the experiences of this study's research participants in Greece but by the rising trends of 
global inequality.

This paper furthers the international debate about the devastating effects of austerity, which are multi-faceted, extensive and deep, and clearly undermine people's personal and social well-being, and the need to challenge them and fight for another society that centres around the needs of people, for the sake of the welfare state, the social work profession, the service users and social justice for all (Garrett \& Bertotti, 2017; Pentaraki, 2013). A clear mandate for the social work profession towards this end is reflected in the statement against austerity by the International Federation of Social Workers (IFSW, 2016), produced while in Greece by the professional social work associations of Greece, Iceland, Ireland, Italy, Portugal, Spain and the UK. It is up to social workers, collectively and individually within and across countries and in collaboration with other progressive organis- ations, to make this mandate a reality (Pentaraki, 2013).

Notes on contributors

Maria Pentaraki, M.S.W., Ph.D., works at Queen's University Belfast, Northern Ireland. Before that she held academic posts in England and Greece where she was also the Head of one of the largest social work departments. She has a wide range of research interests such as international social work, social work practice under austerity, shared austerity reality, grassroots community solidarity structures, gender-based violence, dating and teenage relationship abuse violence and LGBT issues. She has been actively involved in the peace and justice movement throughout her life in many countries in which she has lived.

Konstantina Dionysopoulou is a mental health social worker with a Masters Degree in Education, Human Rights and Social Discrimination and trained in group analysis and family therapy. She lives in Greece. Since 2009 she has worked in psychiatric, therapeutic and community mental health units for adults and children and from 2015 she has worked in a community unit with children and adolescents with a history of abuse, neglect 
or domestic violence. She is a member of the Association of Social Workers of Greece ( $\Sigma \mathrm{K} \wedge \mathrm{E})$.

\section{Disclosure statement}

No potential conflict of interest was reported by the authors.

\section{References}

2 Abramovitz, M., \& Zelnick, J. (2010). Double jeopardy: The impact of neoliberalism on care workers in the United States and South Africa. International Journal of Health Services, 40(1), 97-117. doi: 10.2190/HS.40.1.f[Crossref], [PubMed], [Web of Science $®$ ], [Google Scholar]

3 Andersen, J, Schoyen, M, Hviden, B. (2017). Changing Scandinavian welfare states. In Taylor-Gooby, P., Leruth, B., \& Chung, H. (Eds.), After Austerity: Welfare State Transformation in Europe After the Great Recession (pp. 89-114). Oxford: Oxford University Press. [Google Scholar]

4 Aronson, J., \& Sammon, S. (2000). Practice amid social service cuts and restructuring: Working with the contradictions of small victories. Canadian Social Work Review, 17(2), 167-187. [Google Scholar]

5 Baines, D., Cunningham, I., \& Shields, J. (2017). Filling the gaps: Unpaid (and precarious) work in the nonprofit social services. Critical Social Policy, 0261018317693128. [Google Scholar]

6 Baines, D., Cunningham, I., Campey, J., \& Shields, J. (2014). Not profiting from precarity: The work of nonprofit service delivery and the creation of precasiousness. Just Labour, 22. Retrieved from

http://justlabour.journals.yorku.ca/index.php/justlabour/arti cle/view/ [Google Scholar]

7 Baines, D., Davis, J. M., \& Saini, M. (2009). Wages, working conditions, and restructuring in ontario's social work profession. Canadian Social Work Review/Revue Canadienne de Service Social, 59-72. Retrieved from http://www.jstor.org/stable/41669902 [Google Scholar] 
8Bauman, Z. (2013). Liquid modernity. London: Wiley. [Google Scholar]

9 Beck, U. (1992). From industrial society to the risk society: Questions of survival, social structure and ecological enlightenment. Theory, Culture \& Society, 9(1), 97123. [Google Scholar]

10 Braun, V., \& Clarke, V. (2006). Using thematic analysis in psychology. Qualitative Research in Psychology, 3(2), 77101. doi: 10.1191/1478088706qp063oa[Taylor \& Francis Online], [Google Scholar]

11 Butler, J. (2009). Frames of war: When is life grievable? London: Verso. [Google Scholar]

12 Casas-Cortés, M. (2014). A genealogy of precarity: A toolbox for rearticulating fragmented social realities in and out of the workplace. Rethinking Marxism, 26(2), 206-226. doi: 10.1080/08935696.2014.888849[Taylor \& Francis Online], [Google Scholar]

13 Chan, S., \& Tweedie, D. (2015). Precarious work and reproductive insecurity. Social Alternatives, 34(4), 5.[Web of Science ${ }^{\circledR}$ ], [Google Scholar]

14 Chung, H., \& van Oorschot, W. (2010). Employment insecurity of European individuals duringthe financial crisis: A multi-level approach. Working paper on the reconcialiation of work and welfare in Europe. European Commission Sixth Framework Programme. Retrieved from https://www.ssoar.info/ssoar/bitstream/handle/document/1 9796/ssoar-2010-chung_et_alemployment_insecurity_of_european_individuals.pdf?seq uence $=1$ [Google Scholar]

15 Clayton, J., Donovan, C., \& Merchant, J. (2015). Emotions of austerity: Care and commitment in public service delivery in the north east of England. Emotion, Space and Society, 14, 24-32. doi:

10.1016/j.emospa.2014.11.004[Crossref], [Web of Science $®$ ], [Google Scholar]

16 Comaroff, J., and J. L. Comaroff. (2012). Theory from the south: Or, How Euro-America Is Evolving Toward Africa. 
Anthropological Forum: A Journal of Social Anthropology and Comparative Sociology 22 (2), 113-131. doi:

10.1080/00664677.2012.694169[Taylor \& Francis Online], [Google Scholar]

17 Cunningham, I., Baines, D., \& Shields, J. (2017). "You've just cursed Us": precarity, Austerity and Worker's Participation in the Non-Profit Social Services. Relations Industrielles/Industrial Relations, 72(2), 370-393. doi:

10.7202/1040405ar[Crossref], [Web of Science

$\circledR$ ], [Google Scholar]

18 Cunningham, I., Baines, D., Shields, J., \& Lewchuk, W. (2016). Austerity policies,'precarity' and the nonprofit workforce: A comparative study of UK and Canada. Journal of Industrial Relations, 58(4), 455-472. doi: 10.1177/0022185616639309[Crossref], [Web of Science ®], [Google Scholar]

19 Dominelli, L. (1999). Neo-liberalism, social exclusion and welfare clients in a global economy. International Journal of Social Welfare, 8(1), 14-22. [Google Scholar]

20 Duschinsky, R., Lampitt, S., \& Bell, S. (2016). Sustaining social work: Between power and powerlessness. Oxford:

Palgrave Macmillan.[Crossref], [Google Scholar]

21 Economou, M., Angelopoulos, E., Peppou, L. E., Souliotis, K., Tzavara, C., Kontoangelos, K., \& Stefanis, C. (2016).

Enduring financial crisis in Greece: Prevalence and correlates of major depression and suicidality. Social Psychiatry and Psychiatric Epidemiology, 51(7), 10151024. doi: 10.1007/s00127-016-1238-z[Crossref], [PubMed], [Web of Science $®$ ], [Google Scholar]

22 Elliott, L., \& Atkinson, D. (1999). The age of insecurity. Verso. [Google Scholar]

23 Ettlinger, N. (2007). Precarity unbound. Alternatives, 32(3), 319-340. [Google Scholar]

24 Evans, B., Richmond, T., \& Shields, J. (2005). Structuring neoliberal governance: The nonprofit sector, emerging new modes of control and the marketisation of service delivery. Policy and Society, 24(1), 73-97. doi: 
10.1016/S1449-4035(05)70050-3[Taylor \& Francis Online], [Google Scholar]

25 Fabricant, M., Burghardt, S. F., \& Epstein, I. (1992). The welfare state crisis and the transformation of social service work. New York: Routledge. [Google Scholar]

26 Ferguson, D (2017). Homeless teachers: 'I wouldn't talk about it, I was so ashamed' Retrieved from

https://www.theguardian.com/education/2017/may/23/hom eless-teachers-ashamed-housing-crisisprofessionals [Google Scholar]

27 Froud, J., Johal, S., Moran, M., \& Williams, K. (2017). Outsourcing the state: New sources of elite power.

Theory, Culture \& Society, 34(5-6), 77-101. doi:

10.1177/0263276417717791[Crossref], [Web of Science

®], [Google Scholar]

28 Gair, S. \& Baglow, L. (2017). Seeing it like it is: Australian social work students' experiences of balancing study, work, and compulsory field placement. Australian Social Work, Accepted for Publication. doi:

10.1080/0312407X.2017.1377741[Taylor \& Francis Online], [Google Scholar]

29 Garrett, P. M., \& Bertotti, T. F. (2017). Social work and the politics of 'austerity': Ireland and Italy. European Journal of Social Work, 20(1), 29-41. doi:

10.1080/13691457.2016.1185698[Taylor \& Francis Online], [Web of Science $®$ ], [Google Scholar]

30 Giannakopoulos, G., \& Anagnostopoulos, D. C. (2016). Psychiatric reform in Greece: An overview. British Journal of Psychology Bulletin, 40(6), 326-328. [Google Scholar]

31 Golightley, M. (2017). Social work under neo-liberalism: Fellow sufferer or wounded healer?. British Journal of Social Work, 47(4), 965-972. doi:

10.1093/bjsw/bcx068[Crossref], [Web of Science $\circledR$ ], [Google Scholar]

32 Harvey, D. (2005). A brief history of neoliberalism. Oxford: Oxford University Press. [Google Scholar]

33 Hermann, C. (2014a). Structural adjustment and 
neoliberal convergence in labour markets and welfare: The impact of the crisis and austerity measures on European economic and social models. Competition \& Change, 18(2), 111-130. doi:

10.1179/1024529414Z.00000000051[Crossref], [Google Scholar]

34 Hermann, C. (2014b). Crisis, structural reform and the dismantling of the european social model(s). Economic and Industrial Democracy, 1-18, doi:

10.1177/0143831X14555708[Crossref], [Google Scholar]

35 Ivancheva, M. P. (2015). The age of precarity and the new challenges to the academic profession. Studia Universitatis Babes-Bolyai. Studia Europaea, 60(1), 3947. [Google Scholar]

36 IFSW (2016) IFSW Statement from The Solidarity Symposium on Social Work and Austerity. Retrieved from http://ifsw.org/news/ifsw-statement-from-the-solidaritysymposium-on-social-work-and-austerity/ [Google Scholar]

37 Kalleberg, A. L. (2009). Precarious work, insecure workers: Employment relations in transition. American Sociological Review, 74(1), 1-22. doi:

10.1177/000312240907400101[Crossref], [Web of

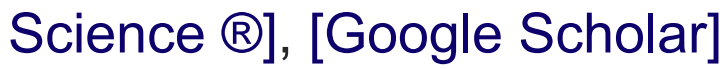

38 Kalleberg, A. L. (2011). Good jobs, bad jobs: The rise of polarized and precarious employment systems in the United States, 1970s-2000s. New York, NY: Russell Sage. [Google Scholar]

39 Kalleberg, A. L. (2013). Globalization and precarious work. Contemporary Sociology, 42 (5)700-706. doi: 10.1177/0094306113499536[Crossref], [Web of Science ®], [Google Scholar]

40 Karagkounis, V. (2017). Social work in Greece in the time of austerity: Challenges and prospects. European Journal of Social Work, 20(5), 651-665. doi:

10.1080/13691457.2016.1255593[Taylor \& Francis Online], [Web of Science $®$ ], [Google Scholar] 
41 Karamessini, M. (2015). The Greek social model: Towards a deregulated labour market and residual social protection. The European Social Model in Crisis: Is Europe Losing Its Soul, 230-288. [Google Scholar]

42 Karamessini, M., \& Rubery, J. (Eds.) (2014). Women and austerity: The economic crisis and the future for gender equality. New York: Routledge. [Google Scholar]

43 Kokaliari, E. (2016). Quality of life, anxiety, depression, and stress among adults in Greece following the global financial crisis. International Social Work, 0020872816651701. [Google Scholar]

44 Kretsos, L. (2014). Youth policy in austerity Europe: The case of Greece. International Journal of Adolescence and Youth, 19(supp. 1), 35-47. doi:

10.1080/02673843.2013.862730[Taylor \& Francis Online], [Google Scholar]

45 Lee, C. K., \& Kofman, Y. (2012). The politics of precarity: Views beyond the United States. Work and Occupations, 39(4), 388-408. doi:

10.1177/0730888412446710[Crossref], [Web of Science ®], [Google Scholar]

46 Levitas, R. (2012). The just's umbrella: Austerity and the big society in coalition policy and beyond. Critical Social Policy, 32(3), 320-342. [Google Scholar]

47 Lorenz, W. (2017). European policy developments and their impact on social work. European Journal of Social Work, 20(1), 17-28. doi:

10.1080/13691457.2016.1185707[Taylor \& Francis Online], [Web of Science ${ }^{\circledR}$ ], [Google Scholar]

48 Lorey, I. (2015). State of insecurity: Government of the precarious. London: Verso Books. [Google Scholar]

49 Mahmud, T. (2015). Precarious existence and capitalism: A permanent state of exception. Southwestern University Law Review, 44, 699-726. [Google Scholar]

50 McNally, D. (2011). 'Global slump: The economics and politics of crisis and resistance'. Oakland, CA: PM Press. [Google Scholar] 
51 Millar, K. M. (2017). Toward a critical politics of precarity. Sociology Compass, 11(6), e12483. [Google Scholar]

52 Näsström, S., \& Kalm, S. (2015). A democratic critique of precarity. Global Discourse, 5(4), 556-573. doi:

10.1080/23269995.2014.992119[Taylor \& Francis Online], [Google Scholar]

53 Neilson, D. (2015). Class, precarity, and anxiety under neoliberal global capitalism: From denial to resistance. Theory \& Psychology, 25(2), 184-201. doi:

10.1177/0959354315580607[Crossref], [Web of Science ®], [Google Scholar]

54 Neilson, B., \& Rossiter, N. (2005). From precarity to precariousness and back again: Labour, life and unstable networks. Fibreculture, 5 (022), 1-19. [Google Scholar]

55 OECD. (2016). Income inequality remains high in the face of weak recovery. Retrieved from

http://www.oecd.org/social/inequality.htm [Google Scholar]

56 Oxfam. (2017). An economy for the 99\%: It's time to build a human economy that benefits everyone, not just the privileged few. Oxfam GB for Oxfam International. [Google Scholar]

57 Papadopoulos, T., \& Roumpakis, A. (2013). Familistic welfare capitalism in crisis: Social reproduction and antisocial policy in Greece. Journal of International and Comparative Social Policy, 29(3), 204-224. doi:

10.1080/21699763.2013.863736[Taylor \& Francis Online], [Google Scholar]

58 Parrott, L. (2014). Social Work and Poverty. London: Policy Press. [Google Scholar]

59 Pathe, S. (2014). Homeless professor protests conditions of adjuncts. Retrieved from http://www.pbs.org/newshour/making-sense/homelessprofessor-protests-conditions-adjuncts/ [Google Scholar]

60 Pentaraki M. (2013) "If we do not cut social spending, we will end up like Greece": challenging consent to austerity through social work action. Critical Social Policy, 33(4), 700-711. doi: 10.1177/0261018313489941[Crossref], 
[Web of Science ${ }^{\circledR}$ ], [Google Scholar]

61 Pentaraki M. (2015). The executive committee of the Greek professional association of social work in an age of austerity: Examining its response. European Journal of Social Work, 18(1), 140-155. doi:

10.1080/13691457.2013.844683[Taylor \& Francis Online], [Web of Science ${ }^{\circledR}$ ], [Google Scholar]

62 Pentaraki, M. (2017a). "I am in a constant state of insecurity trying to make ends meet, like our service users": Shared austerity reality between social workers and service users-towards a preliminary conceptualisation. British Journal of Social Work, 47 (4), 1245-1261.[Web of Science ®], [Google Scholar]

63 Pentaraki, M. (2017b). Practicing social work in a context of austerity: Experiences of public sector social workers in Greece. European Journal of Social Work, Sept, 112. [Google Scholar]

64 Pentaraki, M. (2018a). Austerity common sense and contested understandings of the austerity measures within a leadership of a professional association of social workers. European Journal of Social Work, 1-12. doi: 10.1080/13691457.2018.1435507[Taylor \& Francis Online], [Google Scholar]

65 Pentaraki, M. (2018b). Social work practice of hospital social workers under the structural adjustment program in Greece: Social workers protecting the right to health care within the context of neoliberalism. Czech and Slovak Social Work- reviewed scientific journal for fields of social work, 18 (4), 7-20. Available at http://www.socialniprace.cz/soubory/sp4-2018_web180831114230.pdf\#page $=62$ [Google Scholar]

66 Pentaraki, M., \& Speake, J. (2015). Reclaiming hope within the geopolitics of economic bullying: The case of SYRIZA and post referendum Greece, AntipodeFoundation.org, 20 October, Retrieved from http://antipodefoundation.org/2015/10/20/reclaiming-hopein-greece/ [Google Scholar] 
67 Pradella, L. (2015). The working poor in Western Europe: Labour, poverty and global capitalism. Comparative European Politics, 13(5), 596-613. doi:

10.1057/cep.2015.17[Crossref], [Web of Science

$®]$, [Google Scholar]

68 Puig-Barrachina, V., Vanroelen, C., Vives, A., Martínez, J. M., Muntaner, C., Levecque, K., \& Louckx, F. (2014).

Measuring employment precariousness in the European working conditions survey: The social distribution in Europe. Work, 49(1), 143-161.[PubMed], [Google Scholar]

69 Saar-Heiman, Y., Lavie-Ajayi, M., \& Krumer-Nevo, M. (2017). Poverty-aware social work practice: Service users' perspectives. Child \& Family Social Work, 22(2), 10541063. doi: $10.1111 / \mathrm{cfs} .12325$ [Crossref], [Web of Science ®], [Google Scholar]

70 Salomon, M. E. (2015). Of austerity, human rights and international institutions. European Law Journal, 21(4), 521-545. [Google Scholar]

71 Seifert, A. M., Messing, K., Riel, J., \& Chatigny, C. (2007). Precarious employment conditions affect work content in education and social work: Results of work analyses. International Journal of Law and Psychiatry, 30(4), 299310. doi: 10.1016/j.ijlp.2007.06.004[Crossref], [PubMed], [Web of Science ${ }^{\circledR}$ ], [Google Scholar]

72 Shamai, M. (2017). Is poverty a collective trauma? A Joint Learning Process with Women Living in Poverty in the City of Haifa in Israel. British Journal of Social Work Published Online 31 October doi:10.1093/bjsw/bcx116z[Web of Science $®$ ], [Google Scholar]

73 Sheedy, M. (2013). Core themes in social work: Power, poverty, politics and values. Maidenhead: McGraw-Hill Education (UK). [Google Scholar]

74 Sobotka, T., Skirbekk, V., \& Philipov, D. (2011). Economic recession and fertility in the developed world. Population and Development Review, 37(2), 267-306. [Google Scholar] 
75 Smith, M., Cree, V. E., MacRae, R., Sharp, D., Wallace, E., \& O'Halloran, S. (2016). Social suffering: Changing organisational culture in children and families social work through critical reflection groups-insights from Bourdieu. British Journal of Social Work, 47(4), 973-988. [Google Scholar]

76 Standing, G. (2011). The precariat: The new dangerous class. London: Bloomsbury Academic.[Crossref], [Google Scholar]

77 Stolorow, R. D. (2009). The economic crisis as collective trauma. Trauma Psychology Newsletter, 4(2), 5. [Google Scholar]

78 Thorkelson, E. (2016). Precarity outside: The political unconscious of French academic labor. American Ethnologist, 43(3), 475-487. doi:

10.1111/amet.12340[Crossref], [Web of Science ®], [Google Scholar]

79 Tompa, E., Scott-Marshall, H., Dolinschi, R., Trevithick, S., \& Bhattacharyya, S. (2007). Precarious employment experiences and their health consequences: Towards a theoretical framework. Work, 28(3), 209-

224.[PubMed], [Google Scholar]

80 Triliva, S., \& Georga, A. (2014). Austerity and precarity:

The social milieu creeps into the psychotherapeutic context. Rivista di Psicologia Clinica, (1). [Google Scholar]

81 Vosko, L., \& Clark, L. F. (2009). Gendered precariousness and social reproduction. In F. Vosko, M. MacDonald, \& I. Campbell (Eds.), Gender and the contours of precarious employment (pp. 26-42). London: Routledge. [Google Scholar]

82 Vosko, L. F., MacDonald, M., \& Campbell, I. (Eds.). (2009). Gender and the contours of precarious employment. New York: Routledge. [Google Scholar]

83 United Nations Human Rights, Office of the High Commissioner. (2015). Greek crisis: Human rights should not stop at doors of international institutions, says UN expert. Retrieved from 
http://www.ohchr.org/EN/NewsEvents/ [Google Scholar] Wallace, J., \& Pease, B. (2011). Neoliberalism and Australian social work: Accommodation or resistance? Journal of Social Work, 11(2), 132-142. doi:

10.1177/1468017310387318[Crossref], [Web of Science

®], [Google Scholar] 